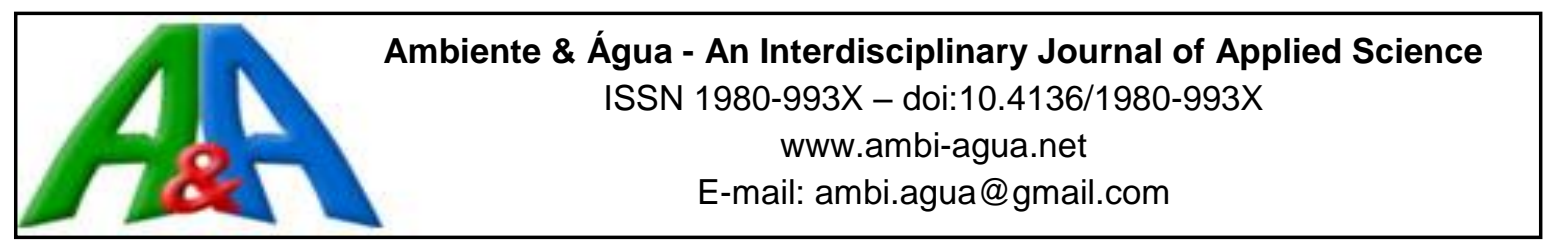

\title{
Participatory guarantee system, equivalence and quality control in a comparative study on organic certifications systems in Europe and Brazil
}

ARTICLES doi:10.4136/ambi-agua.2213

Received: 20 Nov. 2017; Accepted: 17 May 2018

\author{
Luiz Ermindo Cavallet'; Maurizio Canavari²; Paulo Fortes Neto ${ }^{3 *}$ \\ ${ }^{1}$ Universidade Estadual do Paraná (UNESPAR), Paranaguá, PR, Brasil \\ Departamento de Ciências Biológicas. E-mail: luiz.cavallet@unespar.edu.br \\ ${ }^{2}$ Alma Mater Studiorum, Bologna, Emilia-Romagna, Italy \\ Department of Agricultural Sciences. E-mail: maurizio.canavari@unibo.it \\ ${ }^{3}$ Universidade de Taubaté (UNITAU), Taubaté, SP, Brasil \\ Programa de Pós-graduação em Ciências Ambientais (PPGCA) \\ E-mail: paulofortes.neto@gmail.com \\ *Corresponding author
}

\begin{abstract}
Although organic agriculture in Brazil targets mainly local consumers, there is growing demand for research related to commercializing this sector abroad. A study was done in Europe on the perception of entities related to this theme, specifically on Participatory Guarantee Systems (PGS), the feasibility of equivalence between the countries, and control procedures. An exploratory study was conducted through interviews with five organic certification bodies, two in Switzerland, three in Italy, and with a producer association in Italy. PGS is little known in Europe in general and it is suggested that it be better disseminated in the member countries. PGS has been evaluated positively for reducing certification costs and promoting benefits from a social aspect, but it can fail in organic compliance and in large scale production. There are significant differences that must be overcome in order to establish equivalence, such as the lack of homogeneity among European countries on control procedures, the existence of PGS in Brazilian legislation, lack of wild crop products in Europe, different conversion periods, and the requirement of a higher number of inspections in Brazil. Equivalence is seen as beneficial to both Europe and Brazil, and it would therefore be appropriate to promote its viability. The Brazilian law on organic agriculture is taken as very restrictive and complex.
\end{abstract}

Keywords: environmental sustainability, organic certification body, organic production systems.

\section{Sistema de garantia participativa, equivalência e controle de qualidade em um estudo comparativo sobre sistemas de certificação orgânica na Europa e no Brasil}

\section{RESUMO}

Embora a agricultura orgânica no Brasil atinja principalmente aos consumidores locais, há uma crescente demanda por pesquisas relacionadas à comercialização com o exterior neste setor. Uma pesquisa foi realizada na Europa sobre a percepção de entidades relacionadas a este tema, especificamente sobre Sistemas Participativos de Garantia (SPG), a viabilidade da

This is an Open Access article distributed under the terms of the Creative Commons Attribution License, which permits unrestricted use, distribution, and reproduction in any medium, provided the original work is properly cited. 
equivalência entre os países e os procedimentos de controle. Um estudo exploratório foi realizado através de entrevistas com cinco organismos de certificação orgânica, dois na Suíça, três na Itália e uma associação de produtores na Itália. O SPG é pouco conhecido na Europa em geral e é sugerido divulgar melhor nos países membros. O SPG foi avaliado positivamente para reduzir os custos de certificação e promover os benefícios de um aspecto social, mas pode falhar na conformidade orgânica e na produção em grande escala. Existem diferenças significativas para estabelecer equivalência, como a falta de homogeneidade entre os países europeus em procedimentos de controle, a existência de SPG na legislação brasileira, a falta de produtos do extrativismo vegetal na Europa, diferentes períodos de conversão e a exigência de um maior número de inspeções no Brasil. A equivalência foi considerada benéfica para ambos e seria apropriado fazer esforços para torná-la viável. A legislação brasileira sobre agricultura orgânica é considerada muito restritiva e complexa.

Palavras-chave: organismo de certificação orgânica, sistemas de produção orgânica, sustentabilidade ambiental.

\section{INTRODUCTION}

Due to the growing appreciation of products related to environmental sustainability, organic production systems have become increasingly more economically important in recent years. Global retail sales of organic food and beverages reached 81.6 billion dollars in 2015, a growth of about $10 \%$ over the previous year. Between 2000 and 2015, the market expanded nearly four times and such growth might still continue. North America and Europe consume the most organic products, about $90 \%$ of the total (Willer and Lernoud, 2017; Seufert et al., 2017). Specifically considering the economic dimension of organic production systems, resource constraints experienced by farmers regarding their production and commercialization are usually highlighted. Also, consumer need is often associated with product quality (Canavari and Olson, 2007). Consequently, providing a certification service becomes an important aspect of ensuring organic quality. Certification guarantees the confidence of those involved in the production system by making transparency in the system possible, just as with any other food system (Frewer et al., 2014). International audit certification plays a predominant role in production and organic trade. The basis of its operation is the periodic inspection on the rural property by an organic compliance body (ODC). Audit certification, also referred to as "third party", is based on the technical audit procedure. The audit can be broadly defined as a systematic procedure whereby an organization evaluates its practices and operations in order to ascertain conformity with certain pre-established criteria, and these criteria may be legal requirements. There is no universally accepted definition of the term "audit", so the peculiarities of the activities to be audited must be observed. The addition of an audit procedure tends to raise the final cost of the organic product since it is run by a private organization that charges the certified operators for its services.

This has made it necessary to look for alternative systems for organic production systems certification, which has always given rise to discussion regarding its proper legal framework in each country. Regarding alternative organic certification systems in place of the audit system, several formal certification systems have been developed, such as internal control systems (ICS), which are mainly destined for export markets, full government certification, as used in Denmark, and participatory guarantee systems (PGS), aimed mainly at local markets. In terms of propagation, alternatives to third-party certification for compliance assessment are ICS and PGS, which were developed in parallel (Sacchi et al., 2015; Mikkelsen and Lundǿ, 2016; Nelson et al., 2015). 
In Brazil, the legislation allows organic production systems two alternatives to the audit system, direct sales to the consumer, in which the certified product does not need to carry the organic seal and PGS, carried out by a Participatory Conformity Assessment Body (OPAC), certified and supervised by the Ministério da Agricultura, Pecuária e Alimentação - Ministry of Agriculture, Livestock and Food. The product certified by this system has the official national organic label (Brasil, 2012). PGS is a system based on the farmers' own ability to establish control and regulatory mechanisms in the organic production chain in order to comply with the general rules established by the national certification legislation. Thus, PGS does not necessarily depend on records and inspections to be carried out by a technician or external auditor in the production unit, as required by an audit procedure (Martinez, 2013).

The application of this system foresees that the ones involved assume a tacit and full commitment to the principles of organic production, as well as an active role in the supervision of all process levels. (Caldas et al., 2012; Home et al., 2017). However, PGS is not practiced in Europe due to the constraints of law. This is major problem in the organic certification of equivalence with Brazil, as organic quality control procedures differ between both. On the other hand, an increasing convergence between organic certification systems internationally is clear. Therefore, technical and conceptual procedures used in the control of organic quality in Brazil are becoming important, considering discussions to set criteria to establish equivalence for certification procedures with other countries. Taking into account only the case between Brazil and Europe, it is expected that approximation of the organic systems of quality certification might focus especially on the standardization of the main theoretical and regulatory frameworks; equivalence between the two systems would be a natural consequence of that approach.

This study explored the opinions of institutions in Europe, which operate with the certification of organic agriculture, and focused on topics such as PGS, equivalence of certification and organic quality control procedures. It also discusses practical applications of research in Brazil.

\section{MATERIALS AND METHODS}

Using a survey as a technical procedure, a study was carried out using a qualitative approach. Its results should be interpreted as exploratory, as further quantitative research is planned for the future. As a sampling design, two European countries were selected, Italy and Switzerland, which have different profiles, the first one belonging to the European Union and the second not. The institutions studied in Italy were: ProB.E.R. - Associazione Produttori Biologici e Biodinamici Emilia Romagna (Organic and Biodynamic Producers Association of the Region of Emilia-Romagna) and the ODCs IMC - Mediterranean Institute of Certification, ICEA - Istituto Certificazione Etica e Ambientale (Institute of Certification in Environmental Ethics), CCPB - Controllo e Certificazione (Control and Certification). In Switzerland the ODCs studied were: FiBL - Research Institute of Organic Agriculture and Bio-Inspecta. The study was conducted by obtaining data on the opinion of professionals appointed by those institutions. The selection of institutions was carried out by researchers from the Agrarian Science Department of the Agrarian College of the University of Bologna, Italy. A structured questionnaire was created for the interviews with ten questions, which were applied in the same way in six interviews in the form of monologue, with each interview lasting approximately one hour and a half. The research covered the following topics: European certification systems, laws and regulations, sanctions, incentives, packaging and labels, marketing and sales, participatory guarantee systems (PGS), control procedures and possibility of equivalence. For the present study, only the last 3 topics were considered the most relevant. Six English translations of documents were obtained, each of which was considered as a datum for a qualitative analysis, 
which is an adaptation of the research model carried out by Molteni and Troilo (2003). The qualitative analysis used is considered adequate, and it is prevalent in publications related to the organic food market, including the issue of environmental certification (Dias et al., 2015). From the contents of each interview an individual interpretation of three selected topics was made, considering the context thereof and their integration in the European Union, Italy, Switzerland and Brazil. Data were collected from January to June 2013 in Bologna, Italy and Frick, Switzerland.

\section{RESULTS AND DISCUSSION}

The results consist of the notes made by the interviewers and are presented separately in the two sampling sites, namely Italy (Table 1) and Switzerland (Table 2). Each site is separated into 3 study topics (Participatory Guarantee System, Equivalences between the two systems of Organic Quality Control). As instituições ProB.E.R. (Organic and Biodynamic Producers Association of the Region of Emilia-Romagna), IMC (Mediterranean Institute of Certification), ICEA (Institute of Certification in Environmental and Ethics), CCPB (Control and Certification), FiBL (Research Institute of Organic Agriculture) and Bio-Inspecta will be referred to in the discussion respectively as ProBER, IMC, ICEA, CCPB, FiBL and BioInspecta.

\subsection{Considerations in Italy on Participatory Guarantee System (PGS)}

The interviewees were unanimous in stating that PGS is beneficial for Brazil, and that its main advantage is to reduce the final cost of organic product, as long as inspection is done on a voluntary basis (Table 1). This point is worthy of note, since the assertion that PGS reduces costs is historically the main reason for its creation and implementation as guarantee of organic quality. This is consistent with the assertion from many authors who claim that this occurs in Brazil and foreign countries (Sacchi et al., 2011; Corsi, 2012; Dabbert et al., 2012; Home et al., 2017).

Thus, PGS may represent a way to also lower certification costs in Europe, especially for groups of small farmers' direct sales or short chain. In addition to lowering costs, the participatory certification system has the additional advantage of ensuring consumers organic quality while enabling small farmers to avoid the consequent difficulties of audit certification (Home, et al., 2017). Although PGS is known for reducing the final cost of organic certification, there have been efforts with audit certification that aim work around this problem through inter institutional cooperation. In Paraná state, for instance, Programa Paranaense de Certificação de Produtos Orgânicos (PPCPO) - Paranaense Program for the Certification of Organic Products provides organic farmer certification free from charge by means of university outreach. The same involves state public universities, Instituto de Tecnologia do Paraná (TECPAR) - Paraná Technology Institute - and state government (Cavallet et al., 2013). Another point regarding PGS made by interviewees, mainly by the Institute of Certification of Environmental Ethics (ICEA), is that participatory certification creates confidence in the quality of the product, in addition to facilitating the creation of a marketplace. This position is important as most of the other respondents pointed out that PGS promotes an increased risk of non-compliance with organic quality.

On the other hand, ICEA and ProBER interviewees were in Brazil and experienced the field procedures of this system. This is possibly related to the fact that the ICEA interviewee also stated that PGS increases credibility in organic quality assurance. This may demonstrate that on-site verification of the application of PGS certification procedures by organic operators enhances the credibility of the quality assurance system. 
Table 1. Points made by interviewees in Italy on the organic production system used in Brazil and Europe, addressing the topics of participatory certification, equivalence between the two systems, and the control of organic quality.

\begin{tabular}{|c|c|}
\hline Topics & Main Points \\
\hline $\begin{array}{l}\text { Participatory } \\
\text { Guarantee System (PGS) }\end{array}$ & $\begin{array}{l}\text {-Decreases the certification cost and has greater civil participation } \\
\text {-Creates confidence in product quality } \\
\text {-Increase risk of non-compliance with organic quality } \\
\text {-Promotes healthy relationship between social factors and the property } \\
\text {-Has meaningful differences from the European system } \\
\text {-Is considered as a self-certification } \\
\text {-Does not allow large-scale production } \\
\text {-Is suitable for Brazilian and Latin American reality } \\
\text {-Is practically unknown in Europe }\end{array}$ \\
\hline $\begin{array}{l}\text { Equivalences } \\
\text { between the two systems }\end{array}$ & $\begin{array}{l}\text {-Define a strategy to overcome the differences between the two systems } \\
\text {-Obtaining an agreement will depend on political efforts of both parties. } \\
\text {-Favors that } 95 \% \text { of the inputs are the same in both systems } \\
\text {-Equivalence is beneficial for both countries }\end{array}$ \\
\hline $\begin{array}{l}\text { Organic Quality } \\
\text { Control }\end{array}$ & $\begin{array}{l}\text {-All items are checked at least once a year } \\
\text {-Control cost is high, but it is more efficient } \\
\text {-Control efficiency is related to the technical assistance to producers } \\
\text {-Intensity of inspections is made according to the level of risk } \\
\text {-No homogeneity of procedures between control bodies } \\
\text {-No uniformity of procedures between countries } \\
\text {-Updating of knowledge for the auditors is done only once a year } \\
\text {-Lack of training regarding the main risks } \\
\text {-In general, there is lack of uniformity of procedures } \\
\text {-Should take advantage of Brazilian experience with its new regulations }\end{array}$ \\
\hline
\end{tabular}

In addition, ICEA qualified participatory certification in a positive way, as it promotes the efficient use of the territory and social interaction among farmers. The advantage on social aspect attributed to PGS is consistent and well founded, as it promotes empowerment for groups of farmers who base their activities on lasting social processes, strengthening their connection with their local communities. This way, the combination of tradition and upward collaboration within social structures at a local level allows this type of certification to overcome its challenges and guarantee its future as an alternative system to audit certification (Home et al., 2017). On the other hand, the interviewees also raised some unfavorable points for PGS. For example, the IMC interviewee asserted that it does not allow the farmer to have an individual operator certificate in the organic sector because the certificate is issued to the institution to which he belongs. The ProBER observed the PGS' impossibility with the production of large quantities, which would be required for import and export. Finally, CCPB asserted that PGS is considered a self-certification and could fail as an organic quality guarantee, and the organic world market would hardly accept it as a certification system. Nevertheless, such points were not unanimous among the interviewees, as well as among some authors who claim that PGS could be convenient to Europe, suggesting that PGS illustrates an example of a certification system to improve the current organic certification systems in Europe (Dabbert et al., 2012).

\subsection{Considerations in Italy on equivalence}

ProBER., IMC had the majority opinion of the interviewed professionals, in that there are many problems that equivalence of certification systems for organic products between Brazil and Europe may engender (Table 1), but equivalence must be sought. According to the ProBER interviewee the equivalence between countries will only be achieved if they have the same control system and currently this does not occur. The main problem is the existence of PGS in Brazil, which is not included in European legislation. IMC interviewee stated that 
"... international relations that could unite Brazil and Europe in an equivalence regime and facilitate trade between Brazil and Europe without requiring double certification", and also that "There are still conditions that make it difficult to recognize, and consequently there is a need to certify the product twice." This type of difficulty is due to the specific characteristics of the certifications of conformity for each country, as pointed out by Alves et al. (2012), It is neither simple nor quick to enact regulations to make the products subject to mandatory certification. Instead, it is a systematic process in which procedures require an appropriate legislative framework, as well as adequate technological infrastructure and cooperation from every party involved. In addition, the product certification process requires participation of different professionals in the organic production sector, which is one reason for the slowness of process. While there may be significant differences in the legislative framework, there is the fact that the European legislation led to the installation and development of the framework of an organic quality control system in Brazil. It follows that $95 \%$ of agricultural inputs are the same in both countries. This is a technically favorable feature of obtaining equivalence. The CCPB interviewee mentioned that it would not be difficult for equivalence to be achieved, when he used the expression "Therefore, I do not see great barriers to the fact that European and Brazilian legislation can be considered equivalent." The ICEA interviewee was the most optimistic about this issue and even stressed that the present research would be important for this.

This type of research can be very useful in order to reinforce the achievement of a treaty of possible equivalence between the European Union and Brazil. " He even volunteered to work personally with the ministries of agriculture and foreign affairs in Italy to request assistance for this cause. Therefore, the opinion was unanimous that it is important to establish the equivalence of organic certification between Brazil and Europe. While there are problems to be overcome, efforts should be made to accomplish it.

\subsection{Considerations in Italy on the organic quality control system}

Regarding the procedures of organic quality control, all of the interviewees had similar views regarding the technical aspects existing in Italy. The CCPB interviewee talked about it, saying that in Italy the control bodies (ODC) must be registered with the national accreditation body. After approval, the Ministry of Agriculture and Forestry delegates the supervision of the control of private bodies to the Inspection of Food Quality Control and to the 20 provincial governments and 2 autonomous governments. This report is consistent with Dabbert et al. (2012). In addition, the production, processing and distribution of the organic sector in Italy and Europe must be checked at least once a year. Thus, it is argued that the control cost is higher than in Brazil. On the other hand, these procedures are more effective for the control of organic quality (Table 1). In Italy, there is a need for an increasing number of assessments according to the risk of non-compliance, therefore inspections are on average 1.3 to 1.4 times a year. There are inspections at all levels within the production chain, from seed to sales. On the other hand, there is no checklist of equal items for all ODCs; each has its own list. This means that, in Italy, the technical inspection process in organic production units may vary from region to region, which is also observed by Genaro and Roselli (2008). This may be an indication that the European organic quality control system has problems with lack of harmonization of procedures among its countries. In Italy, professionals qualified to control organic quality can be from agronomy, agrarian sciences, cartography, agricultural engineering, biology, chemistry and natural sciences and must participate annually in technical updates. Thus, the CCPB interviewee states that risks with organic non-compliance are considered to be associated mainly with lack of harmonization of procedures, lack of inspectors' professional preparation and lack of availability of minimally sufficient technical information. Also, as stated by ICEA and ProBER, it is important for Europe to work together with Brazil on their respective experiences in organic 
quality control, since the Brazilian experience can help to make European legislation in this sector more appropriate and consistent. This would be convenient not only in terms of control procedures, but also in relation to the performance of public ODCs accreditation bodies. The IMC respondent further stated that the cost of organic quality control in Italy is higher, but considers it more complete and efficient. Thus, he pointed out that "Therefore, confronting the two control systems they do not have the same effectiveness, because in Europe the control is much more punctual compared to the control that is practiced in Brazil, where on the contrary the Internal Control System is applied". The author of the IMC has always referred to the participative system with the technical name of "Internal Control System", and affirms that the existence of the PGS in Brazil is the main item that makes it difficult for an approximation between the two countries regarding the harmonization of technical control procedures. The ICEA interviewee added something relevant when he said that "If it a dialogue for equivalence were to start, it would be very important to understand how it works, whether it is the activity of controlling the certification or the supervisory activity of the competent Brazilian public bodies." On the other hand, the ProBER interviewee, who said that he worked for more than 20 years with organic producers, did not highly value the effectiveness of the means of control for organic quality assurance, citing that "... because it is clear that if one wants to do an organic management in the easiest way, that is, he does day and night management with not allowed chemical control, for this farmer control does not suffice one inspection per year." He added that "Perhaps one inspection each month would not be enough". He also stressed that more important than the control system is the availability of technical assistance to the farmer, because " without adequate technical assistance it is better not to do organic farming." He also thinks that more important than the control system would be to know how the farmer thinks, the physical conditions of the location of his unit of production, and what are the unit's main problems. It should be noted here that this vision of the ProBER interviewer departs somewhat from conventional certification, where the control procedure is based on annual inspections, and reminds more the approach of participatory guarantee. One might even argue that it fits within the broader context of organic agriculture, which is the agroecological approach, as Cotrim and Dal Soglio (2016) argue.

\subsection{Considerations in Switzerland on PGS}

Responders from both institutions (FiBL and Bio-Inspecta) did not go as far on issues related to participatory certification as the responders in Italy did. However, it was also indicated that "this system is profitable for the Brazilian reality, but it is unlikely to be accepted in Europe in the near future" (Table 2). In addition, "it is suitable for the local market, but not for the export market. Retailers accept it, farmers want it and also some local consumers, but the big sales mechanisms do not, because they consider it to be a step backwards in relation to the credibility of organic quality". According to these notes, it is reasonable to assume that a large volume of sales of organic product is not important for Brazilian consumption. In Brazil, there are local and regional consumption chains, which do not include the large supermarket chains. Thus, the operators are not interested in a large amount of sales of these products, either for ideological reasons, or due to the structure of the system itself (Rover, 2011). However, there is a lack of product at the international level, so that one of the great challenges today for organic agriculture is increasing the supply of organic products. Therefore, large-scale production of these products is something that every producing country should consider, whether or not they are exporters (Willer and Lernoud, 2017). However, the responder from FiBL also mentioned that "in Europe PGS is not well known and its terms have not yet been discussed. So it probably will take a long time for it to be recognized in Europe as an organic certification system". They said that such difficulty increases, given that Europe usually takes more time to make decisions on the commercial sector. Due to this, it was suggested that efforts 
be taken "to promote in Europe greater PGS dissemination practiced in Brazil". This suggestion is important for the Brazilian organic sector, insofar as this strategy could tackle other problems related to the acceptance of this system, such as the mistaken view that it will necessarily induce a lack of credibility in organic quality.

The responders in Italy also said that PGS could help the European organic certification system itself, since it is characterized by being constantly discussing its internal structure (Dabbert et al., 2012). A probable reason for lack of knowledge of PGS in Europe is due to the way in which other organic certification systems have emerged and continue to operate within it.

This aligns with Caldas et al. (2012), who studied the lack of successful implementation of PGS in the region of Andalusia, Spain and concluded that one of the reasons for this failure is the existence of audit certification, which is the only way to guarantee the organic quality for farmers interested in selling organic products. Therefore, unlike PGS, it is clear that organic production systems certification by audit is of great importance in the European context. However, this may fail to assess the social dimension. For example, Nowacki et al. (2009) tested the methodology in rural properties in Paraná state, Brazil, to test specific state legislation on compulsory environmental auditing.

Table 2. Points made in Switzerland on the organic production system used in Brazil and Europe, addressing the topics of participatory certification, equivalence between the two systems, and organic quality control.

\begin{tabular}{|c|c|}
\hline Topics & Main Points \\
\hline $\begin{array}{l}\text { Participatory } \\
\text { Guarantee System } \\
\text { (PGS) }\end{array}$ & $\begin{array}{l}\text {-Does not exist in European legislation for organic products } \\
\text {-Contributes to discredit the organic certification seal } \\
\text {-Will take a long time to be accepted in Europe } \\
\text {-Makes it difficult to set equivalence with other countries } \\
\text {-Impairs the export of Brazilian organic products } \\
\text {-Is beneficial to Brazil and other Latin American countries }\end{array}$ \\
\hline $\begin{array}{l}\text { Equivalences } \\
\text { between the two } \\
\text { systems }\end{array}$ & $\begin{array}{l}\text {-In Brazil the legislation is very detailed when compared to the European legislation } \\
\text {-In Brazil, the legislation appears to show equivalence with other countries } \\
\text {-Too much detail hinders the viability of equivalence with Europe } \\
\text {-The existence of participatory certification is the main problem } \\
\text {-Will be hampered by the slow pace of policy decisions in the European Community } \\
\text {-Brazil is said to have very protectionist market policies } \\
\text {-Certifiers can request individual recognition in Europe } \\
\text { - It is suggested that Brazil set equivalence with countries which already have it with } \\
\text { Europe } \\
\text {-Seek equivalence with Latin American countries } \\
\text {-Simplify the control system aiming at the establishment of equivalence } \\
\text { - Current need for recertification is for both countries }\end{array}$ \\
\hline $\begin{array}{l}\text { Organic Quality } \\
\text { Control }\end{array}$ & $\begin{array}{l}\text {-Switzerland has a less-complex control system than Brazil } \\
\text {-In Europe, there are both system modes (public and private) } \\
\text {-In Denmark it is public, in Germany it is private and in Spain there are both } \\
\text {-In Europe, the inspection is made by the country where they are headquartered } \\
\text {-The control body must be accredited by the Ministry of Agriculture } \\
\text {-Once accredited, they must report to the European Union } \\
\text {-In Europe, the operator must be inspected at least once a year } \\
\text {-In Brazil, the organic operator must be inspected at least twice a year } \\
\text {-In Europe, there are two types of organic seal, one for the public and another for the } \\
\text { private } \\
\text {-In Europe, private seals are considered more reliable } \\
\text {-In Europe, private seals are more detailed due to the requirements of the legislation } \\
\text {-In Brazil, the control system is much more restrictive than in Europe }\end{array}$ \\
\hline
\end{tabular}


They observed that it proved quite sensitive regarding legal obligations and polluting potential, but it was not enough to assess the social dimensions of the agrarian environment, and was therefore an instrument geared to the legal environmental aspects. Thus, the verification of the conformity of a normative criterion through an audit may fail when it comes to the social aspects. This may be an indication that the audit procedure applied to organic production system may fail to verify criteria linked to what is socially fair, which is one of the three pillars of sustainability. This justifies the inclusion of PGS as this, as alternative to the certification system audit, may be more conducive to sustainability due to being more sensitive to the social dimensions of the agrarian environment.

\subsection{Considerations in Switzerland on equivalence}

Several points were raised in Switzerland on equivalence, including many already declared in Italy, especially with respect to meaningful differences between the two systems (Table 2). Differences such as: lack of standardization of procedures in Europe for organic certification in wild crop production, as well as the conversion period in Brazil, which is much more restrictive than in Europe. Another claim deals with how detailed Brazilian legislation is and the fact that the farmer must register all the inputs entering the farm. It was also pointed out that the technical regulations for organic quality control in Brazil have many secondary documents such as standards, technical guides and forms. This latest note is certainly related to third party organic certification, for on the other hand PGS in Brazil does not present itself as excessively bureaucratic in its structure. Nelson et al. (2015) emphasize that aspect of PGS, and also point that excessive bureaucracy in third party for certification can act as a barrier to small producers seeking to take part in the organic market. Therefore, the PGS simplified internal structure can help to reduce the problem of significant divergence between Brazil and Europe, as it considers the Brazilian model of organic certification too bureaucratic in general. To that end, Switzerland stated that Brazilian law on the organic sector appears to have been drawn up aimed at easy recognition and equivalence with several countries, because it is very detailed and presents itself as prepared to achieve equivalence with several markets. However, this situation makes it difficult for Brazil to import European organic products, as well as ingredients and processes. Therefore, excessive restriction in regulating the organic sector facilitates exports from Brazil to other countries, but that makes it difficult to import from Europe. It follows that the only way for a company in Europe to export some organic products to Brazil is to contract with a Brazilian certification body and recertify the entire procedure. For example, Switzerland exports chocolate and sugar products to Brazil, but it is mandatory to recertify them. The statement on the need to recertify European products to export them to Brazil is appropriate, when it is based on the regulatory framework COAGRE 11/2012 (Brasil, 2012). It establishes procedures for organic product registration, labeling and internalization. Also, in Italy it was mentioned that such regulatory framework reduced the possibility of trade between Europe and Brazil in the sector. In fact, a recertification procedure for organic products increases their final cost. In part, this may have the effect of limiting the development of the Brazilian domestic market for organic products due to the limitation of imports. At that point, the equivalence would be suitable for Brazil once it increased domestic trade of imported products at a lower cost due to eliminating the need to recertify. On the other hand, it was stated that equivalence would pave the way for the export of Brazilian organic products, mainly animal feed, since there is no such raw material in Europe. Another important issue pointed out in Switzerland was the conversion period. In Brazil, this is established by ODC and varies according to the type of agriculture, the previous use of the place of cultivation, and also considers the current ecological and social situation. However, a minimum period of 12 months of organic management is established for crop production of annual crops, 18 months for perennial crops, and at least 12 months of organic cultivation or settling are established for perennial pastures. In Europe, the conversion 
period is not as detailed and, different from Brazilian law, it does not consider the social situation of rural property (Brasil, 2011; European Community, 2007). There are clear points where both systems differ. For example, in Europe, the conversion period cannot begin before the day on which the control body begins to register the production unit. In Brazil, this may be possible, since some official body, such as EMATER, for example, provides a document certifying that the farm already has all organic management conditions from certain dates before the initial registration. Still, it was observed that in order to obtain equivalence between Brazil and Europe there should be some meaningful political effort on both sides. Such an attitude has been important for the regulation of the organic sector, at least in Brazil, since the discussion of the relationship between organic agriculture and agroecology has always been in political dispute, since it defines principles, association criteria and even scientific legitimacy (Abreu et al., 2012). Finally, it was mentioned that any organic certification body in Brazil can apply for recognition particularly to Europe, whether inside or outside the country. For this, one must present their standards and control system to the registration body in the intended country, and the latter must check for conformity between both systems.

On the other hand, an important structural principle of PGS is that consumers should be included in the inspection process. For the present case, one of the biggest challenges regarding equivalence is how this can happen when physically they cannot reciprocally visit production units because of distance. It is observed that none of the interviewees of the 6 entities interviewed in this study (ProBER, IMC, ICEA, CCPB, FiBL and Bio-Inspecta) mentioned anything about this aspect. Possibly they did not because this kind of information would have been technically very specific and went unnoticed. Entities in Switzerland have probably not done so because they have been opposed to the PGS from the outset since the current European law for the sector does not allow it, so there would be no reason to dwell on technical details of the subject. It is also possible that, as the PGS is little known in Europe, the respondents did not have in mind the clear relation of this technical aspect to the question of equivalence. But it is considered opportune to make some speculation as to how this kind of problem could be solved or, at least mitigated, by assuming that the equivalence between the two countries had to be consolidated. As mentioned previously, the feasibility of on-site verification of the application of PGS certification procedures in Brazil by representatives of consumers in the organic sector in Europe could be a way forward. This is reinforced when one realizes that the ICEA interviewee who was in Brazil experienced the field procedures of this system and concomitantly stated that the PGS increases the credibility in the organic quality assurance. It is very likely that it would not be very different for consumers, or representatives of these. Another way that could be proposed to approach the distant consumer would be to use hierarchy management structures of a more general level within a given certification body. One example is the Ecovida network, one of the largest certifiers with PGS in Brazil. According to Martinez (2013), within the Ecovida network the farmers' associations are small, usually have between 5 and 10 members and decide how they want to make their system of meetings and visits. At a second level, by geographic area, what is defined in the network are the Regional Centers, which are composed of several producer associations, some technical assistance NGOs and some groups of consumers that meet periodically. The latter also establish their own methodology for conducting visits. From the Regional Core, an Ethics Board is formed, which will analyze the available information on farmers to decide whether or not to grant them the seal of the network. Thus, local consumers participating in the Regional Centers and the Ethics Council could be used as potential actors for European consumer engagement in the inspection procedures. 


\subsection{Considerations in Switzerland on the organic quality control system}

With respect to the organic quality control system in Europe, the FiBL responder said that it is considered simple when compared to the Brazilian one, except in Germany where it is more complex (Table 2). There is a norm that regulates the control bodies for certifications in general, including organic production systems, and it establishes the operating requirements. There are basic requirements that are checked with annual inspection, according to the main rules that establish how the control should be done. As did the responders in Italy, they emphasized that two annual inspections are required in Brazil, which means "a significant difference to the European system where, in general, only one inspection is needed". The responders from FiBL said that in Europe there are two types of organic control systems, public or private, and some countries have only the private system and some have both. For example, Spain has both systems, Germany and Italy have only the private control system, and Denmark has only the public one. The case in Denmark stands out for the present study, in which organic quality assurance is part of a public certification system for food services including organic products in the menu, along with a sales volume monitoring system and a training of food service workers. Such importance increases as public agencies and institutions in Europe are considered to be quite influential in general by pointing to more appropriate ways of food consumption through government purchases (Mikkelsen and Lundǿ, 2016). As with the responders in Italy, regarding the supervision of organic quality control bodies, they said that it is public in every country and also accountable to each country internally. The accreditation body belongs to the ministry of agriculture, which records and decides whether to accept the private ODC or not. Once accepted, each ODC must report directly to the European Community. In this way, FiBL said that "the whole system has a simple structure, where basic requirements serve to guide organic quality control". There was an emphatic statement on the question of the organic product label from the Bio-Inspecta responder. For example, in organic products the European label has different laws for public and private control bodies. For private brands, the law is more restrictive and establishes the need to present more details about the products. As a result, consumers tend to rely more on private labels. Therefore, the more detailed the label, the more useful it will be in organic quality control as a whole. Thus, he said that "the private labels may contribute to greater control of organic quality". Regarding this subject, Zorn et al. (2012) said that for the private inspection bodies' supervision, it is necessary to guarantee an equal minimum level of control intensity in a competitive market environment, as in Europe. Finally, both responders pointed out emphatically that "Brazil has a very detailed and very restrictive legislative framework that guides the regulation of organic production systems". This may be true if the evolution of the regulatory system that has occurred in the country since its inception in the 1970s is observed, as described by Alves et al. (2012), as presented previously. However, over-regulation does not always align with the fundamental principles of organic agriculture. Darnhofer et al. (2010) studied organic agriculture in Europe focused on the production unit level related to compliance regulations. Although organic agriculture certainly has the potential to meet the expectations of organic food consumers, the authors have shown that some certified organic production units cannot. This is because their practices often comply with regulations, but not with the principles of organic agriculture. This trend has been called the "conventionalization" of organic agriculture. In addition, they argue that it is not enough to focus on structural changes to properly understand the dynamics within organic agriculture and its potential impact on the ability to meet the expectations of consumers and decision makers. Instead, it needs to assess whether the observed changes are or are not being met in accordance with the principles and values that are the foundation of organic agriculture. Thus, it can be assumed that over-regulation in Brazil may not make sense at all when related to the principles of organic agriculture. On the other hand, this statement values PGS, in which the theoretical basis is close to deregulation. This could be another argument in favor of the fact that the

\section{IPABH}

Rev. Ambient. Água vol. 13 n. 4, e2213 - Taubaté 2018 
approximation between the system of control of the organic production systems between Brazil and Europe could bring benefit to both, from the point of view of its constant improvement.

\section{CONCLUSIONS}

The participatory organic quality guarantee system (PGS) is seen in Europe as attractive because it reduces the final cost of the product and also promotes the social integration of local communities. However, there are unfavorable aspects, such as the fact that PGS is not feasible for large-scale production and that its procedures may incur an increased risk of organic noncompliance. However, the position that PGS creates a risk of organic non-compliance was not unanimous, since there were conflicting opinions, which suggest that PGS can create confidence in the quality of the product and also facilitate marketing. In Europe, PGS is not well understood and it would be important to develop a strategy to promote a better understanding of its benefits. This procedure could even assist the improvement of European legislation for this sector. The equivalence between both organic certification systems was considered economically beneficial for both countries. However, there are meaningful differences that make it potentially difficult to establish, such as lack of standardization of regulations among member countries and lack of organic certification for wild crop products in Europe. Also, in Brazil there are the existence of PGS, the existence of different conversion periods, greater number of inspections in the production unit, and excessive detailing of the legislation in the sector. In general, it is seen that Europe is aware of Brazilian reality regarding the context of social inclusion that involves organic production systems. This suggests that Brazilian organic products can be disseminated in Europe with more emphasis on being socially fair, economically viable and environmentally friendly.

\section{ACKNOWLEDGEMENTS}

CNPq from Ministério da Ciência Tecnologia, Inovações e Comunicações, the postdoctoral internship grant.

\section{REFERENCES}

ABREU, L. S.; BELLON, S.; BRANDENBURG, A.; OLLIVIER, G; LAMINE, C. DAROLT, M. R. et al. Relações entre agricultura orgânica e agroecologia: desafios atuais em torno dos princípios da agroecologia. Desenvolvimento e Meio Ambiente, Curitiba, v. 26, p. 143-160, 2012. http://dx.doi.org/10.5380/dma.v26i0.26865

ALVES, A. C. de O.; SANTOS, A. L. de S. dos; AZEVEDO, R. M. M. C. de. Agricultura orgânica no Brasil: sua trajetória para a certificação compulsória. Revista Brasileira de Agroecologia, n. 7, v. 2, p. 19-27, 2012.

BRASIL. Ministério da Agricultura Pecuária e Abastecimento. Instrução Normativa $n^{\circ}$ 46, de 6 de outubro de 2011. Estabelece o regulamento técnico para os sistemas orgânicos de produção animal e vegetal. Diário Oficial [da] União, Brasília, DF, 7 out. 2011.

BRASIL. Ministério da Agricultura, Pecuária e Abastecimento. Nota Técnica Coagre n. 11 de 13 de março de 2012. Procedimentos para registro, rotulagem e internalização de produtos orgânicos no âmbito do Ministério da Agricultura, Pecuária e Abastecimento. Diário Oficial [da] União, Brasília, DF,13 mar. 2012. 
CALDAS, N. V.; ANJOS, F. S. dos; BEZERRA, A. J.; CRIADO, E. A. Certificação de produtos orgânicos: obstáculos à implantação de um sistema participativo de garantia na Andaluzia, Espanha. Revista de Econonomia e Sociologia Rural, v. 50, n. 3, p. 455472, 2012. http://dx.doi.org/10.1590/S0103-20032012000300004

CANAVARI, M.; OLSON, K. D. Organic Food. Consumers Choices and Farmers Opportunities. New York, 2007.

CAVALLET, L. E.; RIBEIRO, H. I.; MARTINS, C. B. Cooperação técnica para certificação de agricultura orgânica na região Litorânea do Paraná. Revista Acadêmica: Ciências Agrárias e Ambientais, v. 11, n. 2, p. 169-174, 2013. http://dx.doi.org/10.7213/academica.10.S02.NT02

COTRIM, D. S.; DAL SOGLIO, F. K. Construction of knowledge agroecological: questioning the process. Revista Brasileira de Agroecologia, v. 11, n. 3, p. 259-271, 2016.

CORSI, A. L'agricoltura biologica: fattore di sviluppo per le piccole aziende o di difesa dell'ambiente? In: SAQUET, M. A.; DANSERO, E.; CANDIOTTO, L. Z. P. Geografia para a cooperação do desenvolvimento territorial: experiências brasileiras e italianas. São Paulo: Outras Expressões, 2012. p. 267-286.

DABBERT, S.; ABAY, C.; BELLIÈRE, S. R. Economic analysis of certification systems in organic food and farming: synthesis report of results. Deliverable 23 of the EU FP7 CERTCOST project. 2012. Available on: http://www.certcost.org/Upload/CERTCOST/Document/D23_designed_web.pdf

DARNHOFER, I.; LINDENTHAL, T.; BARTEL-KRATOCHVIL, R.; ZOLLITSCH, W. Conventionalisation of organic farming practices: from structural criteria towards an assessment based on organic principles. A review. Agronomy for Sustainable Development, v. 30, p. 67-81, 2010. https://doi.org/10.1051/agro/2009011

DIAS, V. da V.; SCHULTZ, G.; SCHUSTER, M. da S.; TALAMINI, E.; RÉVILLION, J. P. The organic food market: a quantitative and qualitative overview of international publications. Ambiente \& Sociedade, v. 18, n. 1, p. 155-174, 2015. http://dx.doi.org/10.1590/1809-4422ASOC841V1812015en

EUROPEAN COMMUNITY. Concil Regutation (EC) n 834/2007 of 28 June 2007 on organic production and labeling of organic products and repealing Regulation (EEC) $n^{\circ} 2092 / 91$. Official Journal of the European Union, 20 jul. 2007. 23p.

FREWER, L. J.; FISCHER, A. R.; BRENNAN, M.; BÁNÁTI, D.; LION, R.; MEERTENS, R. M. et al. Risk/benefit communication about food - a systematic review of the literature. Critical Reviews in Food Science and Nutrition, n. 56, n. 10, p. 1728-45, 2014. https://doi.org/10.1080/10408398.2013.801337

GENNARO, B. de; ROSELLI, L. Un'analisi della struttura e del funzionamento del sistema di controllo e certificazione delle produzioni da agricoltura biologica. Agriregionieuropa, v. 4, n. 15, 2008.

HOME, R.; BOUAGNIMBECK, H.; UGAS, R.; ARBENZ, M.; STOLZE, M. Participatory guarantee systems: organic certification to empower farmers and strengthen communities. Journal Agroecology and Sustainable Food Systems, n. 5, v. 41, p. 526-545, 2017. https://doi.org/10.1080/21683565.2017.1279702 
MARTINEZ, S. B. Los Sistemas Participativos de Garantía en el fomento de los mercados locales de productos orgánicos. Polis, v. 12, n. 34, p. 15-29, 2013. http://dx.doi.org/10.4067/S0718-65682013000100002

MIKKELSEN, B. E.; LUNDØ, M. O papel das políticas públicas de aquisição de alimentos orgânicos (POPP) na implementação de estratégias agrícolas e alimentares orgânicas: lições da Dinamarca. Raízes, v. 36, n. 2, p. 45-54, 2016.

MOLTENI, L.; TROILO, G. Le ricerche qualitative. In: MOLTENI, L.; TROILO, G. Ricerche di marketing. Milano, 2003. p. 97-125.

NELSON, E.; TOVAR, L. G.; GUEGUEN, E.; HUMPHRIES, S.; LANDMAN, K.; RINDERMANN, R. S. Participatory guarantee systems and the reimagining of Mexico's organic sector. Agriculture and Human Values, n. 33, p. 373 - 88, 2015. https://doi.org/10.1007/s10460-015-9615-x

NOWACKI, A. C. B. A.; SILVA, E. T. da; GOBBI, E. F.; MARÇAL, C. T.; PASQUALIN, L. A.; ALVES, R. de G. Compulsory environmental audit: study of case in rural properties of Paraná state (Brazil). Scientia Agraria, v. 10, n. 3, p. 233-238, 2009.

ROVER, O. J. Agroecologia, mercado e inovação social: o caso da Rede Ecovida de Agroecologia. Ciências Sociais Unisinos, v. 47, n. 1, p. 56-63, 2011.

SACCHI, G.; ZANASI, C.; CANAVARI, M. Modelli alternativi di garanzia della qualità dei prodotti biologici alla luce della teoria delle convenzioni. Economia agro-alimentare, v. 13, n. 3, p. 57-80, 2011. http://dx.doi.org/10.3280/ECAG2011-003005

SACCHI, G.; CAPUTO, V.; NAYGA, R. Alternative labeling programs and purchasing behavior toward organic foods: the case of the participatory guarantee systems in Brazil. Sustainability, n. 7, p. 7397-416, 2015. http://dx.doi.org/10.3390/su7067397

SEUFERT, V.; RAMANKUTTY, N.; MAYERHOFER, T. What is this thing called organic? - How organic farming is codified in regulations. Food Policy, n. 68, p. 10-20, 2017. https://doi.org/10.1016/j.foodpol.2016.12.009

WILLER, H.; LERNOUD, J. The world of organic agriculture. Statistic and emerging trends 2017. Frick: FiBL; Bonn: IFOAM, 20 Feb. 2017. Available on: http://www.organic-world.net/yearbook/yearbook-2017.html

ZORN, A.; LIPPERT, C.; DABBERT, S. Supervising a system of approved private control bodies for certification: The case of organic farming in Germany. Food Control, v. 25, n. 2, p. 525-532, 2012. https://doi.org/10.1016/j.foodcont.2011.11.013 